\title{
Analisis Tingkat Kognitif Uji Kompetensi pada Buku Sekolah Elektronik (BSE) Matematika SMP/MTs Kelas VII Kurikulum 2013 Berdasarkan Taksonomi Bloom
}

\author{
Nancy Yunita Susanti ${ }^{1}$, Dinawati Trapsilasiwi ${ }^{2}$, Dian Kurniati ${ }^{2}$ \\ 1 Program Studi Pendidikan Matematika Jurusan P.MIPA, FKIP Universitas Jember \\ Email: dian.kurniati@unej.ac.id \\ DOI: http://dx.doi.org/10.15294/kreano.v6i1.4509 \\ Received: August 2015; Accepted: September 2015; Published: September 2015
}

\begin{abstract}
Abstrak
Buku teks pelajaran berperan penting dan strategis dalam upaya meningkatkan mutu pendidikan dasar dan menengah. Buku teks dilengkapi dengan soal-soal latihan yang belum terklasifikasi tingkat kognitifnya. Penelitian ini bertujuan untuk mengetahui tingkat kognitif soal uji kompetensi beserta persentase masing-masing tingkat kognitif soal uji kompetensi pada BSE Matematika SMP Kelas VII kurikulum 2013 semester 1 maupun semester 2. Jenis penelitian yang digunakan adalah penelitian deskriptif dengan pendekatan kualitatif. Hasil penelitian dapat disimpulkan bahwa soal uji kompetensi BSE Matematika semester 1 mencakup 9 variasi soal dari 24 variasi soal menurut tingkat kognitif Revisi Taksonomi Bloom. Dari 166 pertanyaan, terdapat 6.6\% tingkat C2-faktual; 17\% tingkat C2-konseptual; 22\% tingkat C2-prosedural; 3\% tingkat C3-faktual; 6.6\% tingkat C3-konseptual; 28\% tingkat C3-prosedural; 1.8\% tingkat $\mathrm{C}_{4}$-konseptual; $14 \%$ tingkat $\mathrm{C}_{4}$-prosedural; $0.6 \%$ tingkat C6-konseptual; dan $0 \%$ pertanyaan tingkat yang lainnya. Sedangkan pada BSE Matematika semester 2 mencakup 11 variasi soal. Dari 170 pertanyaan terdapat o.6\%

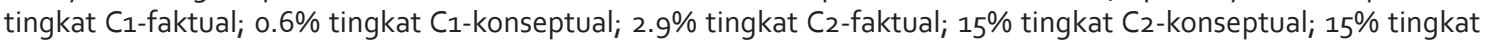
$\mathrm{C}_{2}$-prosedural; 8.2\% tingkat $\mathrm{C}_{3}$-konseptual; 30\% tingkat $\mathrm{C}_{3}$-prosedural; $4.7 \%$ tingkat $\mathrm{C}_{4}$-konseptual; 5.3\% tingkat $\mathrm{C}_{4}$-prosedural; 14\% tingkat $\mathrm{C}_{5}$-konseptual; 4.1\% tingkat C6 konseptual; dan 0\% tingkat yang lain.
\end{abstract}

\begin{abstract}
Textbooks have an important and strategic role in improving the quality of primary and secondary education. Textbook comes with practice questions are not yet classified the cognitive level. The aims of this study are determining the level of cognitive matter competency test along with the percentage of each level of cognitive matter competency test on BSE Class VII SMP Math curriculum 2013 1st half and 2nd semester. Type of research is descriptive research with a qualitative approach. It can be concluded that about half of the competency test BSE Mathematics 1 includes 9 variations of about 24 variations of matter according to the degree of cognitive Revised Bloom's Taxonomy. Of the 166 questions, there is a 6.6\% rate of C2-factual; $17 \%$ C2-conceptual level; 22\% C2-procedural level; 3\% level C3-factual; 6.6\% C3-conceptual level; $28 \%$ level of $C_{3}$-procedural; $1.8 \% C_{4}$-conceptual level; $14 \%$ of $C_{4}$-procedural level; $0.6 \%$ C6-conceptual level; and $0 \%$ of the questions that other level. While in the second half of BSE Mathematics includes 11 variations matter. Of the 170 questions contained $0.6 \%$ level of $C_{1}$-factual; $0.6 \% C_{1}$-conceptual level; $2.9 \%$ rate of $C_{2}$-factual; $15 \%$ C2-conceptual level; 15\% C2-procedural level; 8.2\% C3-conceptual level; 30\% level of $C_{3}$-procedural; 4.7\% C4-conceptual level; 5.3\% rate of $C_{4}$-procedural; $14 \%$ of the $C_{5}$-conceptual level; $4.1 \%$ C6 conceptual level; and the $0 \%$ level to another.
\end{abstract}




\section{PENDAHULUAN}

Matematika merupakan salah satu mata pelajaran di sekolah yang dapat meningkatkan daya pikir siswa dengan kemampuan berpikir logis, analitis, kritis dan kreatif (Hudojo, 2003). Saat ini, kita ketahui bahwa sistem pendidikan di Indonesia sedang mengalami masalah khususnya pada proses pembelajaran matematika. Pada pembelajaran matematika, aspek-aspek seperti pemahaman rumus beserta aplikasinya wajib dimiliki oleh siswa, namun pada kenyataannya masih banyak siswa yang mengalami kesulitan dalam memecahkan masalah matematika. Hal ini juga terbukti dengan hasil laporan TIMSS (Trends In International Mathematics and Science Study) dan PISA (Programme International for Student Assesment).

Berdasarkan laporan TIMSS 2011 para siswa kelas VIII Indonesia menempati posisi ke 38 diantara 42 negara yang berpartisispasi dalam tes matematika. Dari rata-rata skor internasional 500, para siswa Indonesia hanya memperoleh skor rata-rata 386. Skor siswa Indonesia tersebut tertinggal dengan siswa sesama Negara ASEAN seperti Singapura, Malaysia, dan Thailand yang masing-masing mendapatkan skor rata-rata 661, 440, dan 427 (Balitbang, 2011). Namun pada tahun 2012 hasil survey dari lembaga lain yaitu PISA membuat miris kalangan pendidik Indonesia. Hasil survey PISA 2012, menyatakan bahwa kemampuan matematika siswa Indonesia menempati rangking 64 dari 65 negara yang berpartisipasi. Rata-rata skor matematika anak- anak Indonesia 375 yang jauh dari skor rata-rata internasional yaitu 494 (Kemdikbud, 2013).

Untuk menyelesaikan masalah pendidikan dan meningkatkan mutu pendidikan tersebut, masih terdapat beberapa kendala yang menyertainya. Salah satu kendalanya yaitu adanya buku teks. Buku teks tidaklah mengajar, buku teks merupakan suatu sarana pembelajaran namun buku teks memiliki peran yang cukup penting dalam proses pembelajaran karena buku teks bisa digunakan sebagai sumber kedua dalam proses pembelajaran ketika sumber utama (guru) tidak hadir (Greeny dan Petty dalam Tarigan dan Tarigan, 1990).

Terobosan baru telah dilakukan Peme- rintah dengan cara membeli hak cipta buku teks dari penulis atau penerbit. Kemudian buku-buku tersebut disajikan dalam bentuk elektronik atau biasanya disebut dengan Buku Sekolah Elektronik (BSE). Dan untuk kurikulum yang digunakan saat ini atau Kurikulum 2013, Pemerintah telah menyiapkan Buku Sekolah Elektronik (BSE) untuk semua mata pelajaran setiap jenjangnya. Buku Sekolah Elektonik (BSE) dilengkapi soal-soal yang dipakai sebagai latihan ataupun sebagai alat penilaian. Soal-soal yang terdapat dalam buku teks sebaiknya sudah terklasifikasi pertanyaannya sesuai kemampuan kognitif siswa. Dengan soal yang sudah terklasifikasi dapat bermanfaat bagi siswa maupun guru. Bagi siswa, soal yang sudah terklasifikasi tingkat kognitifnya dapat mempermudah siswa dalam mengerjakan soal sehingga siswa dapat menyelesaikannya secara bertahap, dari yang memiliki tingkat kesulitan rendah hingga yang memiliki tingkat kesulitan tinggi. Bagi guru, soal yang sudah terklasifikasi tingkat kognitifnya dapat mempermudah guru untuk mengetahui sampai tingkat kognitif yang seperti apa yang dimiliki oleh siswanya.

Soal latihan dalam buku teks sebaiknya juga sesuai dengan kompetensi dasar yang telah diberikan kepada siswa. Karena di dalam kompetensi dasar terdapat indikator kompetensi yaitu perilaku yang dapat diukur dan diobservasi untuk menunjukkan ketercapaian kompetensi dasar tertentu yang menjadi acuan penilaian mata pelajaran. Indikator tersebut menjadi acuan dalam pembuatan soal. Dalam pembuatan soal juga digunakan kata-kata kerja operasional. Penggunaan kata kerja operasional yang disusun oleh Benjamin S. Bloom sesuai dengan tingkatan taksonomi Bloom digunakan untuk memenuhi tujuan pembelajaran dan memaksimalkan proses pembelajaran.

Taksonomi Bloom, terbagi menjadi tiga ranah atau kawasan ("domain"), yaitu ranah kognitif, ranah afektif dan ranah psikomotor. Pada kurikulum 2013 diharapkan terdapat keseimbangan aspek atau ranah pembelajaran, yaitu kognitif, afektif, dan psikomotor (Oktaviani, 2013). Untuk ranah kognitif Taksonomi Bloom, telah diadakan revisi yang mengakibatkan terjadi pemisahan antara penge- 
tahuan dari proses kognitif. Sehingga, pada Taksonomi Bloom Revisi, tedapat dua dimensi yaitu dimensi pengetahuan dan dimensi proses kognitif (Widodo, 2006).

Rumusan masalah dalam penelitian ini adalah sebagai berikut: (1) Bagaimana tingkat kognitif soal uji kompetensi dalam Buku Sekolah Elektronik (BSE) Matematika SMP/MTs Kelas VII Kurikulum 2013 berdasarkan Taksonomi Bloom? ; dan (2) Berapakah persentase tingkat kognitif soal uji kompetensi pada Buku Sekolah Elektronik (BSE) Matematika SMP/MTs Kelas VII Kurikulum 2013 berdasarkan Taksonomi Bloom?

\section{Buku Sekolah Elektronik (BSE)}

Buku merupakan salah satu sarana penting dalam upaya meningkatkan mutu pendidikan. Dewasa ini, salah satu permasalahan dalam perbukuan adalah ketersediaan buku yang memenuhi standar nasional pendidikan dengan harga murah yang dapat dijangkau oleh masyarakat luas. Untuk mengatasi hal tersebut, Departemen Pendidikan Nasional telah membeli hak cipta buku teks pelajaran dari penulis atau penerbit. Selanjutnya buku-buku tersebut disajikan dalam bentuk buku elektronik dengan nama Buku Sekolah Elektronik (BSE) yang memenuhi syarat kelayakan untuk digunakan dalam proses pembelajaran. Buku yang hak ciptanya telah dimiliki oleh Pemerintah tersedia dalam tiga bentuk yang semua dinamai Buku sekolah Elektronik (BSE), yaitu: (1) BSE Internet, (2) BSE CD, dan (3) BSE Cetak (Nasrullah, 2011). Perihal isi, ketiga bentuk BSE tersebut sama yang membedakan hanya bentuknya saja.

BSE Internet adalah buku teks yang diunggah di internet dengan maksud dapat diunduh oleh siapapun baik untuk dibaca di komputer maupun dicetak dalam jumlah yang terbatas. Sehingga, buku jenis seperti ini dapat mengantisispasi keterbatasan sediaan buku cetak. BSE CD (compact disk) disediakan dengan maksud agar percetakan, penerbit, Pemerintah Provinsi, Pemerintah Kabupaten/ Kota, dan pihak-pihak lain tergerak membantu penyediaan buku teks secara massal. Sedangkan BSE Cetak berbentuk buku konvensional yang harga jual eceran tertingginya (HET-nya) ditentukan oleh Pemerintah. Hal ini dikarenakan hak cipta buku dimiliki oleh Pemerintah.

Buku pelajaran yang sesuai dengan kurikulum 2013 juga ada dalam bentuk Buku Sekolah Elektronik (BSE) yang dapat diakses secara gratis di website Buku Sekolah Elektronik (BSE) Kemdikbud yang beralamat http://bse.kemdikbud.go.id/. Hingga saat ini tersedia 1331 buku yang terdiri dari : 502 buku SD, 238 buku SMP, 338 buku SMA, 222 buku SMK, dan 2 buku Bahasa (Kemdikbud, 2014). Dan pada penelitian ini, BSE yang digunakan adalah BSE internet yang telah diunggah sebelumnya.

\section{Dimensi Pengetahuan dalam Revisi Taksonomi Bloom}

Ada empat macam pengetahuan dalam Revisi Taksonomi Bloom, yaitu pengetahuan faktual, pengetahuan konseptual, pengetahuan prosedural, pengetahuan metakognitif.

Pengetahuan faktual (factual knowledge) merupakan pengetahuan tentang elemen dasar yang harus diketahui siswa untuk mengenal suatu disiplin ilmu atau untuk menyelesaikan masalah di dalamnya (Gunawan, 2015). Ada dua macam pengetahuan faktual, yaitu pengetahuan tentang istilah atau terminologi (Knowledge of terminology) dan pengetahuan tentang rincian dan unsur tertentu (Knowledge of specific details and elements).

Pengetahuan konseptual (conceptual knowledge) merupakan pengetahuan tentang hubungan timbal balik antara elemen-elemen dasar dalam suatu struktur yang memungkinkan elemen-elemen tersebut berfungsi secara bersama-sama. Pengetahuan ini mencakup skema, model, mental, dan teori yang mempresentasikan pengetahuan manusia tentang bagaimana suatu materi kajian ditata dan distrukturkan (Gunawan, 2015). Ada tiga macam pengetahuan konseptual, yaitu pengetahuan tentang klasifikasi dan kategori/penggolongan (Knowledge of classifications and categories), pengetahuan tentang prinsip dan generalisasi (Knowledge of principles and generalizations), dan pengetahuan tentang teori, model dan struktur (Knowledge of theories, models, and structures).

Pengetahuan prosedural (procedural knowledge) merupakan pengetahuan tentang 
bagaimana melakukan suatu hal, metode dan inquiri dan kriteria untuk menggunakan suatu keterampilan, algoritma, teknik, dan suatu metode (Widodo, 2006). Ada tiga macam pengetahuan prosedural, yaitu pengetahuan tentang keterampilan dan algoritma tertentu (knowledge of subject-specific skills and algorithms), pengetahuan teknik dan metode tertentu (knowledge of subject-specific techniques and methods), dan pengetahuan tentang kriteria untuk menentukan kapan menggunakan prosedur yang tepat (Knowledge of criteria for determining when to use appropriate procedures).

Pengetahuan metakognitif (metacognitive knowledge), merupakan pengetahuan yang mencakup tentang kognisi secara umum dan pengetahuan tentang diri sendiri. Penelitian tentang metakognitif menunjukkan bahwa seiring dengan perkembangannya siswa menjadi semakin sadar akan pikirannya dan semakin banyak tahu tentang kognisi, dan apabila siswa bisa mencapai hal ini maka mereka akan lebih baik lagi dalam belajar (Widodo, 2006). Menurut Kramarski (dalam Kamid, 2013), menyatakan bahwa "pengetahuan metakognitif dapat dilihat ketika siswa sadar kemampuan kognitifnya". Contoh, siswa mengetahui bahwa ia mempunyai memori yang kurang baik untuk materi pelajaran tertentu; untuk menilai prestasinya, ia membuat catatan tentang prestasinya. Ada tiga macam pengetahuan metakognitif, yaitu pengetahuan strategi (strategic knowledge), pengetahuan tugas kognitif termasuk pengetahuan kontekstual dan kondisional yang cocok (knowledge about cognitive tasks, including appropriate contextual and conditional knowledge), dan pengetahuan tentang diri sendiri (Self-knowledge).

\section{METODE}

Pendekatan penelitian yang digunakan dalam penelitian ini adalah pendekatan kualitatif. Artinya penelitian yang digunakan untuk meneliti objek yang alamiah dimana peneliti adalah sebagai instrumen kunci, teknik pengumpulan data dilakukan secara triangulasi, analisis data bersifat induktif, dan hasil penelitian kualitatif lebih menekankan makna daripada generalisasi (Sugiyono, 2007). Penelitian deskriptif adalah penelitian yang berusaha mendeskripsikan dan menginterpretasikan sesuatu, misalnya kondisi atau hubungan yang ada, pendapat yang berkembang, proses yang sedang berlangsung, akibat atau efek yang terja$\mathrm{di}$, atau tentang kecenderungan yang tengah terjadi (Arikunto, 2002). Analisis data yang digunakan dalam penelitian ini adalah analisis deskriptif. Data yang terkumpul dalam penelitian deskriptif dapat diklasifikasikan menjadi data kulitatif dan kuantitatif. Data kualitatif dapat dijabarkan dengan kalimat yang dipisahkan menurut kategori. Data kuantitatif berupa angka-angka hasil perhitungan melalui proses untuk mendapatkan persentase.

Penelitian ini merupakan studi kepustakaan. Hal ini dikarenakan data yang digunakan dalam penelitian ini merupakan data pustaka yang siap pakai, artinya peneliti berhadapan langsung dengan bahan sumber yang sudah tersedia (buku teks matematika).

Prosedur penelitian yang digunakan dalam penelitian ini dapat dilihat pada Gambar 1. Sumber data penelitian ini adalah soal Uji Kompetensi yang terdapat dalam Buku Sekolah Elektronik (BSE) Matematika SMP/ MTs Kelas VII Kurikulum 2013 yang diterbitkan oleh Kementrian Pendidikan dan Kebudayaan pada tahun 2014.

Penelitian ini menggunakan metode dokumentasi karena data berupa soal uji kompetensi. Data diperoleh dari Buku Sekolah Elektronik (BSE) Matematika SMP/MTs Kelas VII Kurikulum 2013 terbitan Kementrian Pendidikan dan Kebudayaan tahun 2014.

Untuk menghitung persentase dari masing-masing tingkatan soal uji kompetensi digunakan rumus sebagai berikut.

\[ P=n / N \times 100 \% \]
Keterangan:
$\mathrm{P}=$ nilai persentase yang dicari
$\mathrm{n}=$ banyaknya pertanyaan dari masing
masing tingkatan soal
$\mathrm{N}=$ banyaknya pertanyaan pada uji
kompetensi




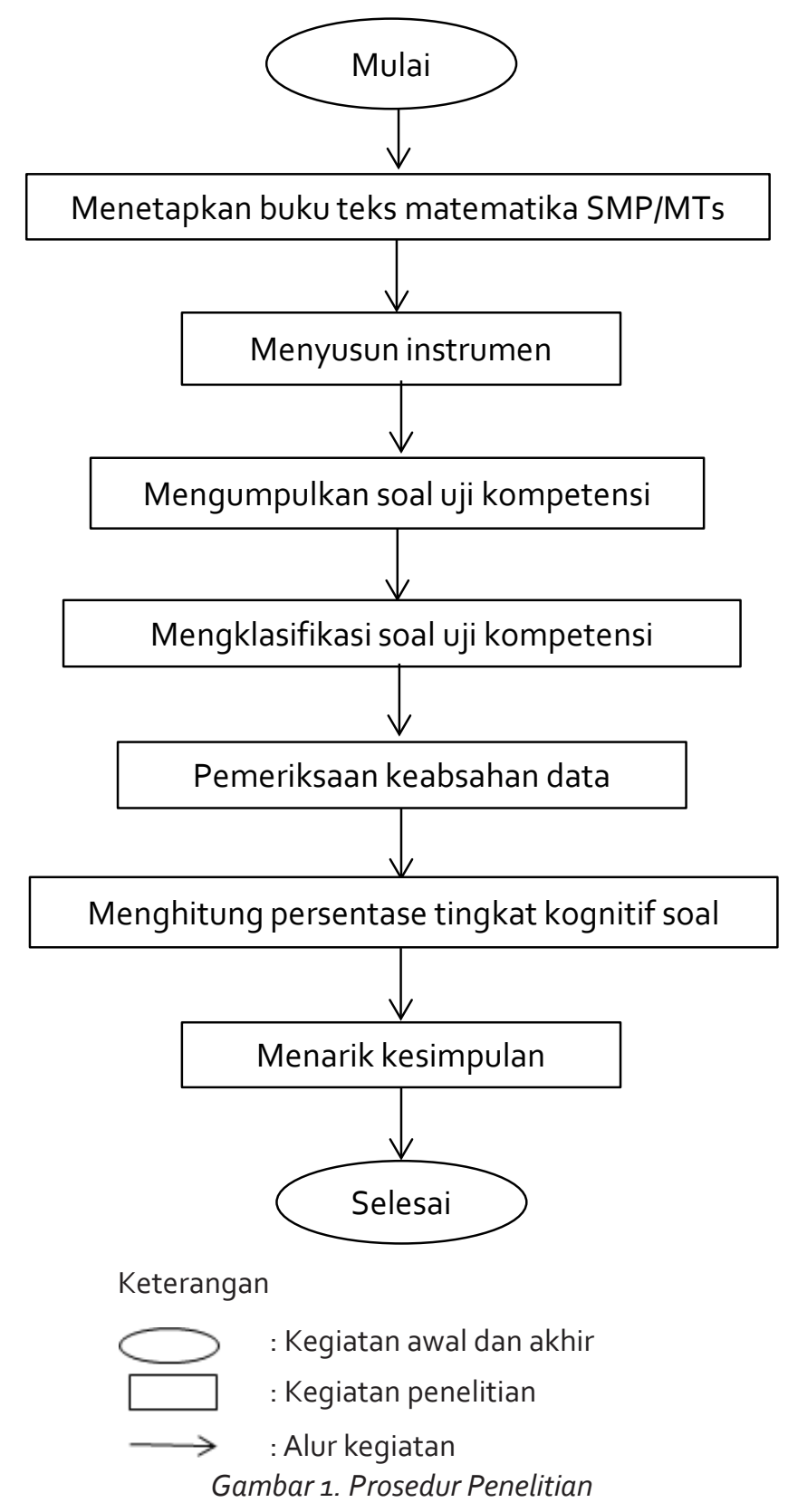

HASIL DAN PEMBAHASAN

Buku Sekolah Elektronik (BSE) SMP/MTs kelas VII kurikulum 2013 terbitan Kementrian Pendidikan dan Kebudayaan (Kemdikbud) pada tahun 2014 (Edisi Revisi) terdiri dari 2 buku, yaitu buku semester 1 dan buku semester 2 . Setiap semester terdapat 4 pokok bahasan, sehingga untuk kelas VII ada 8 pokok bahasan. Uji kompetensi pada 2 buku tersebut, terdiri dari uji kompetensi pada tiap pokok bahasan dan uji kompetensi akhir semester.

Pada Buku Sekolah Elektronik (BSE) SMP/MTs kelas VII kurikulum 2013 terbitan Kementrian Pendidikan dan Kebudayaan
(Kemdikbud) pada tahun 2014 (Edisi Revisi) semester 1, dari 168 pertanyaan terdapat 2 pertanyaan yang tidak dapat diklasifikasikan. Dua pertanyaan tersebut terdapat pada Uji Kompetensi Semester 1 nomor 35 dengan sub soal a dan b.

Pada Buku Sekolah Elektronik (BSE) SMP/MTs kelas VII kurikulum 2013 terbitan Kementerian Pendidikan dan Kebudayaan (Kemdikbud) pada tahun 2014 (Edisi Revisi) semester 2, Dari 178 pertanyaan terdapat 8 pertanyaan yang tidak dapat diklasifikasikan. Pertanyaan tersebut adalah nomor 12 Uji Kompetensi 1, nomor 6 Uji Kompetensi 3, 
nomor 13, 25, 35, 40a, 40b, dan 44a Uji Kompetensi Semester 2.

Analisis tingkat kognitif dalam penelitian ini disajikan dalam bentuk kombinasi antara dimensi pengetahuan dan dimensi proses kognitif serta dalam bentuk persentase yang diperoleh dari klasifikasi tingkat kognitif Revisi Taksonomi Bloom. Hasil analisis setelah dilakukan teknik pemeriksaan keabsahan data untuk keseluruhan uji kompetensi dari BSE Matematika Semester 1 dan dan keseluruhan uji kompetensi dari BSE Matematika Semester 2 dapat dilihat pada Tabel 1. Hasil analisis lebih rinci dari setiap uji kompetensi dalam BSE Matematika semester 1 dapat dilihat pada Tabel $\mathbf{2}$ dan Tabel $\mathbf{3}$ untuk hasil analisis lebih rinci dari setiap uji kompetensi dalam BSE Matematika semester 2.

BSE Matematika semester 1 memuat 166 pertanyaan. Berdasarkaan Tabel 1 dapat dilihat bahwa pada dari seluruh pertanyaan tersebut, persentase terbanyak ditempati oleh soal tingkat $\mathrm{C}_{3}$-prosedural yaitu $28.3 \%$ atau 47 pertanyaan sedangkan soal C6-konseptual memiliki jumlah pertanyaan paling sedikit yaitu 1 pertanyaan atau jika dihitung persentasenya yaitu $0.6 \%$. Sedangkan BSE Matematika semester 2 memuat 170 pertanyaan. Berdasarkaan Tabel 1 dapat dilihat bahwa dari seluruh pertanyaan tersebut, persentase terbanyak ditempati oleh soal tingkat C3-prosedural yaitu 30\%. atau 51 pertanyaan sedangkan soal $\mathrm{C}_{2}$-prosedural dan $\mathrm{C}_{3}$-faktual memiliki jumlah pertanyaan paling sedikit yaitu 1 pertanyaan atau jika dihitung persentasenya yaitu $0.6 \%$.
Dari hasil analisis soal uji kompetensi BSE Matematika semester 1 secara keseluruhan, dapat diketahui bahwa dari seluruh soal uji kompetensi hanya mencakup 9 tingkatan kognitif menurut Revisi Taksonomi Bloom yang artinya terdapat 9 variasi soal dari 24 variasi soal yang dapat terbentuk dari tingkat kognitif menurut Revisi Taksonomi Bloom.

Sama halnya dengan soal uji kompetensi pada BSE Matematika semester 1 , seluruh soal uji kompetensi pada BSE Matematika semester 2 juga tidak mencakup semua tingkatan kognitif menurut Revisi Taksonomi Bloom. Soal uji kompetensi pada BSE Matematika semester 2 mencakup 11 tingkatan kognitif menurut Revisi Taksonomi Bloom atau mencakup 11 variasi soal dari 24 variasi soal yang dapat terbentuk dari tingkat kognitif menurut Revisi Taksonomi Bloom.

Hasil klasifikasi soal uji kompetensi berdasarkan tingkat kognitif Revisi Taksonomi Bloom menunjukkan bahwa seluruh soal yang terdapat pada BSE Matematika semester 1 dan BSE Matematika semester 2 tidak mencakup semua tingkatan kognitif Revisi Taksonomi Bloom. Soal yang terdapat pada dua buku tersebut, hanya mencakup tingkatan $\mathrm{C}_{1}$-faktual, C1-konseptual, C2-faktual, C2-konseptual, C2-prosedural, C3-faktual, C3-konseptual, $C_{3}$-prosedural, $C_{4}$-konseptual, $C_{4}$-prosedural, C5-konseptual, dan C6-konseptual. Jika dilihat lebih rinci setiap dimensi pada Revisi Taksonomi Bloom, pada dimensi pengetahuan tidak terdapat soal yang termasuk dalam jenis pengetahuan metakognitif. Soal-soal yang telah diklasifikasi hanya termasuk dalam tiga

Tabel 1. Persentase Tingkat Kognitif Seluruh Soal Uji Kompetensi pada BSE Matematika Semester 1 dan BSE MAtematika Semester 2

\begin{tabular}{|c|c|c|c|c|c|c|c|c|}
\hline \multirow{2}{*}{$\begin{array}{c}\text { BSE } \\
\text { Matematika }\end{array}$} & \multirow{2}{*}{$\begin{array}{l}\text { Dimensi Pen- } \\
\text { getahuan }\end{array}$} & \multicolumn{6}{|c|}{ Dimensi Proses Kognitif } & \multirow{2}{*}{ - Jumlah } \\
\hline & & $\mathrm{C}_{1}$ & $\mathrm{C}_{2}$ & $C_{3}$ & $\mathrm{C}_{4}$ & $\mathrm{C}_{5}$ & $\mathrm{C6}$ & \\
\hline \multirow{4}{*}{ Semester 1} & $\mathrm{P}_{1}$ & 0 & 6.63 & 3.01 & 0 & 0 & 0 & \multirow{4}{*}{100} \\
\hline & $\mathrm{P}_{2}$ & 0 & 17.46 & 6.63 & 1.82 & 0 & 0.6 & \\
\hline & $P_{3}$ & 0 & 21.69 & 28.3 & 13.86 & 0 & 0 & \\
\hline & $\mathrm{P}_{4}$ & 0 & 0 & 0 & 0 & 0 & 0 & \\
\hline \multirow{4}{*}{ Semester 2} & $\mathrm{P}_{1}$ & 0.59 & 2.94 & 0 & 0 & 0 & 0 & \multirow{4}{*}{100} \\
\hline & $\mathrm{P}_{2}$ & 0.59 & 14.71 & 8.23 & 4.71 & 13.53 & 4.12 & \\
\hline & $P_{3}$ & 0 & 15.29 & 30 & 5.29 & 0 & 0 & \\
\hline & $\mathrm{P}_{4}$ & 0 & 0 & 0 & 0 & 0 & 0 & \\
\hline
\end{tabular}


jenis pengetahuan yang lainnya, yaitu pengetahuan faktual, pengetahuan konseptual, dan pengetahuan prosedural. Hal ini dikarenakan pengetahuan metakognitif merujuk pada proses berpikir.
Dalam hal ini siswa dapat menggunakan ilmu pengetahuan yang telah dikuasainya untuk membangun pengetahuan baru. Serta pengetahuan ini bisa digunakan siswa untuk mengontrol proses-proses kognitifnya atau

Tabel 2. Rincian Persentase Tingkat Kognitif Uji Kompetensi pada BSE Matematika Semester 1

\begin{tabular}{|c|c|c|c|c|c|c|c|}
\hline \multirow{2}{*}{ Uji Kompetensi } & \multirow{2}{*}{ Dimensi Pengetahuan } & \multicolumn{6}{|c|}{ Dimensi Proses Kognitif } \\
\hline & & $\mathrm{C}_{1}$ & $\mathrm{C}_{2}$ & $C_{3}$ & $\mathrm{C}_{4}$ & $C_{5}$ & C6 \\
\hline \multirow{4}{*}{ Uji Kompetensi 1} & $P_{1}$ & 0 & 0 & 5.13 & 0 & 0 & 0 \\
\hline & $\mathrm{P}_{2}$ & 0 & 5.13 & 12.82 & 0 & 0 & 0 \\
\hline & $P_{3}$ & 0 & 30.77 & $33 \cdot 33$ & 12.82 & 0 & 0 \\
\hline & $\mathrm{P}_{4}$ & 0 & 0 & 0 & 0 & 0 & 0 \\
\hline \multirow{4}{*}{ Uji Kompetensi 2} & $P_{1}$ & 0 & 0 & 0 & 0 & 0 & 0 \\
\hline & $P_{2}$ & 0 & 23.53 & 0 & 0 & 0 & 0 \\
\hline & $P_{3}$ & 0 & $29 \cdot 41$ & 47.06 & 0 & 0 & 0 \\
\hline & $\mathrm{P}_{4}$ & 0 & 0 & 0 & 0 & 0 & 0 \\
\hline \multirow{4}{*}{ Uji Kompetensi 3} & $P_{1}$ & 0 & 0 & 8 & 0 & 0 & 0 \\
\hline & $P_{2}$ & 0 & 12 & 0 & 0 & 0 & 0 \\
\hline & $P_{3}$ & 0 & 20 & 36 & 24 & 0 & 0 \\
\hline & $\mathrm{P}_{4}$ & 0 & 0 & 0 & 0 & 0 & 0 \\
\hline \multirow{4}{*}{ Uji Kompetensi 4} & $P_{1}$ & 0 & 0 & 0 & 0 & 0 & 0 \\
\hline & $\mathrm{P}_{2}$ & 0 & 30 & 20 & 0 & 0 & 0 \\
\hline & $P_{3}$ & 0 & 0 & 0 & 50 & 0 & 0 \\
\hline & $\mathrm{P}_{4}$ & 0 & 0 & 0 & 0 & 0 & 0 \\
\hline \multirow{4}{*}{$\begin{array}{l}\text { Uji Kompetensi } \\
\text { Semester } 1\end{array}$} & $P_{1}$ & 0 & 14.67 & 1.33 & 0 & 0 & 0 \\
\hline & $P_{2}$ & 0 & 22.67 & $5 \cdot 33$ & 4 & 0 & 1.33 \\
\hline & $P_{3}$ & 0 & 18.67 & 22.67 & 9.33 & 0 & 0 \\
\hline & $\mathrm{P}_{4}$ & 0 & 0 & 0 & 0 & 0 & 0 \\
\hline
\end{tabular}

Tabel 3. Rincian Persentase Tingkat Kognitif Uji Kompetensi pada BSE Matematika Semester 2

\begin{tabular}{|c|c|c|c|c|c|c|c|}
\hline \multirow{2}{*}{ Uji Kompetensi } & \multirow{2}{*}{ Dimensi Pengetahuan } & \multicolumn{6}{|c|}{ Dimensi Proses Kognitif } \\
\hline & & $\mathrm{C}_{1}$ & $\mathrm{C} 2$ & $\mathrm{C}_{3}$ & $\mathrm{C}_{4}$ & $C_{5}$ & C6 \\
\hline \multirow{4}{*}{ Uji Kompetensi 1} & $P_{1}$ & 5 & 0 & 0 & 0 & 0 & 0 \\
\hline & $\mathrm{P}_{2}$ & 5 & 15 & 15 & 15 & 5 & 5 \\
\hline & $P_{3}$ & 0 & 5 & 20 & 10 & 0 & 0 \\
\hline & $\mathrm{P}_{4}$ & 0 & 0 & 0 & 0 & 0 & 0 \\
\hline \multirow{4}{*}{ Uji Kompetensi 2} & $P_{1}$ & 0 & 0 & 0 & 0 & 0 & 0 \\
\hline & $\mathrm{P}_{2}$ & 0 & 0 & 23.81 & 0 & 0 & 19.05 \\
\hline & $P_{3}$ & 0 & 0 & 57.14 & 0 & 0 & 0 \\
\hline & $\mathrm{P}_{4}$ & 0 & 0 & 0 & 0 & 0 & 0 \\
\hline \multirow{4}{*}{ Uji Kompetensi 3} & $P_{1}$ & 0 & 0 & 0 & 0 & 0 & 0 \\
\hline & $\mathrm{P}_{2}$ & 0 & 10.71 & 0 & 0 & 39.29 & 0 \\
\hline & $P_{3}$ & 0 & 50 & 0 & 0 & 0 & 0 \\
\hline & $\mathrm{P}_{4}$ & 0 & 0 & 0 & 0 & 0 & 0 \\
\hline \multirow{4}{*}{ Uji Kompetensi 4} & $P_{1}$ & 0 & 31.25 & 0 & 0 & 0 & 0 \\
\hline & $P_{2}$ & 0 & 18.75 & 0 & 0 & 6.25 & 0 \\
\hline & $P_{3}$ & 0 & 6.25 & 18.75 & 18.75 & 0 & 0 \\
\hline & $\mathrm{P}_{4}$ & 0 & 0 & 0 & 0 & 0 & 0 \\
\hline \multirow{4}{*}{$\begin{array}{l}\text { Uji Kompetensi } \\
\text { Semester } 2\end{array}$} & $\mathrm{P}_{1}$ & 0 & 0 & 0 & 0 & 0 & 0 \\
\hline & $P_{2}$ & 0 & 18.83 & 7.06 & 2.35 & 11.76 & 2.35 \\
\hline & $P_{3}$ & 0 & 11.77 & 37.65 & 8.23 & 0 & 0 \\
\hline & $P_{4}$ & 0 & 0 & 0 & 0 & 0 & 0 \\
\hline
\end{tabular}


mengendalikan enam tingkatan dimensi proses kognitif, yaitu mengingat, memahami, mengaplikasikan, menganalisis, mengevaluasi, dan mencipta. Soal-soal yang terdapat pada kedua buku ini didominasi oleh soal yang menghasilkan pengetahuan konseptual dan pengetahuan prosedural. Pada dimensi proses kognitif, sudah terdapat soal yang mewakili setiap tingkatannya, yaitu tingkat mengingat, memahami, mengaplikasikan, menganalisis, mengevaluasi, dan mencipta.

BSE Matematika semester 1 mencakup 9 variasi soal dari 24 variasi soal menurut Revisi Taksonomi Bloom. Seperti dijelaskan sebelumnya bahwa tidak terdapat soal jenis pengetahuan metakognitif baik pada dimensi proses mengingat, memahami, mengaplikasikan, menganalisis, ataupun mencipta. Pada buku ini soal yang mendominasi adalah soal yang menghasilkan pengetahuan konseptual dan pengetahuan prosedural. Terutama soal tingkat C3-prosedural memiliki jumlah terbanyak dari tingkatan lainnya. Pada tingkat C3-prosedural diharapkan siswa dapat menjalankan suatu prosedur rutin, keterampilan, teknik, dan metode untuk memecahkan suatu masalah. Jika dilihat dari grafik kombinasi dimensi pengetahuan dan dimensi proses kognitif Revisi Taksonomi Bloom, pada buku ini soal tingkat tinggi terdapat pada jenis C6konseptual dan soal tingkat rendah terdapat pada C2-faktual.

Jika dibandingkan dengan BSE Matematika semester 1, BSE Matematika semester 2 memiliki soal yang lebih bervariasi, yaitu terdapat 11 variasi soal menurut tingkatan kognitif Revisi Taksonomi Bloom. Apabila dilihat dari dimensi proses kognitif, soal uji kompetensi BSE Matematika semester 2 mencakup semua dimensi proses kognitif. Soal terbanyak pada buku ini terdapat pada tingkat $\mathrm{C}_{3}$ prosedural yang mengharapkan siswa dapat menjalankan suatu prosedur rutin, keterampilan, teknik, dan metode untuk memecahkan suatu masalah. Jika dilihat dari grafik kombinasi dimensi pengetahuan dan dimensi proses kognitif Revisi Taksonomi Bloom, pada buku ini soal tingkat tinggi terdapat pada jenis C6konseptual dan soal tingkat rendah terdapat pada $C_{1}$-faktual. Sama halnya dengan BSE Matematika semester 1 , buku ini didominasi oleh pertanyaan yang menghasilkan pengetahuan konseptual dan pengetahuan prosedural.

Tingkat kognitif erat hubungannya dengan bobot suatu soal. Semakin tinggi tingkat kognitifnya (menurut Revisi Taksonomi Bloom) maka semakin tinggi pula kualitas soal tersebut. Dan pada dasarnya soal yang siswa kerjakan harus mencakup semua tingkatan kognitif Revisi Taksonomi Bloom, mulai dari tingkat rendah (C1-faktual) sampai tingkat tinggi (C6-metakognitif). Sebagai dimensi hasil kognitif, soal-soal uji kompetensi harus mencakup keempat jenis pengetahuan terlebih pada soal yang menghasilkan pengetahuan metakognitif. Karena dengan memiliki pengetahuan metakognitif berarti siswa mengetahui bermacam-macam strategi untuk menyelesaikan tugas-tugas belajarnya. Dan sebagai proses kognitif, soal uji kompetensi juga harus mencakup semua jenis proses kognitif, mulai dari mengingat, memahami, dan mengaplikasikan yang termasuk dalam kriteria berpikir tingkat rendah (low order of thinking) hingga menganalisis, mengevaluasi, dan mencipta yang termasuk dalam kriteria berpikir tingkat tinggi (high order of thinking).

\section{SIMPULAN}

Berdasarkan hasil penelitian serta pembahasan hasil penelitian yang terdapat pada bab sebelumnya, maka dapat disimpulkan hal-hal sebagai berikut: (a) Buku Sekolah Elektronik (BSE) SMP/MTs kelas VII kurikulum 2013 terbitan Kementrian Pendidikan dan Kebudayaan (Kemdikbud) pada tahun 2014 (Edisi Revisi) semester 1 terdiri dari 166 pertanyaan yang dapat diklasifikasi. Dari 166 pertanyaan ini, terdapat 11 pertanyaan tingkat C2-faktual, 29 pertanyaan tingkat $\mathrm{C}_{2}$-konseptual, 36 pertanyaan tingkat $\mathrm{C}_{2}$-prosedural, 5 pertanyaan tingkat $\mathrm{C}_{3}$-faktual, 11 pertanyaan tingkat $\mathrm{C}_{3}$ konseptual, 47 pertanyaan tingkat $\mathrm{C}_{3}$-prosedural, 3 pertanyaan tingkat $\mathrm{C}_{4}$-konseptual, 23 pertanyaan tingkat $\mathrm{C}_{4}$-prosedural, dan 1 pertanyaan tingkat C6-konseptual. Hanya terdapat 9 variasi soal dari 24 variasi soal yang ada. Soal tingkatan $C_{3}$-prosedural mendominasi pada buku ini. Sedangkan Buku Sekolah Elektronik (BSE) SMP/MTs kelas VII kurikulum 2013 terbitan Kementrian Pendidikan dan 
Kebudayaan (Kemdikbud) pada tahun 2014 (Edisi Revisi) semester 2 terdiri dari 170 pertanyaan yang dapat diklasifikasi. 1 pertanyaan tingkat $\mathrm{C}_{1}$-faktual, 1 pertanyaan tingkat $\mathrm{C}_{1}$ konseptual, 5 pertanyaan tingkat C2-faktual, 25 pertanyaan tingkat $C_{2}$-konseptual, 26 pertanyaan tingkat $\mathrm{C}_{2}$-prosedural, 14 pertanyaan tingkat $\mathrm{C}_{3}$-konseptual, 51 pertanyaan tingkat $\mathrm{C}_{3}$-prosedural, 8 pertanyaan tingkat $\mathrm{C}_{4}$-konseptual, 9 pertanyaan tingkat $\mathrm{C}_{4}$-prosedural, 23 pertanyaan tingkat $\mathrm{C}_{5}$-konseptual, dan 7 pertanyaan tingkat C6-konseptual. Terdapat 11 dari 24 variasi soal menurut tingkatan Revisi Taksonomi Bloom; (b) Persentase tingkat kognitif soal Uji Kompetensi pada Buku Sekolah Elektronik (BSE) SMP/MTs kelas VII kurikulum 2013 terbitan Kementrian Pendidikan dan Kebudayaan (Kemdikbud) pada tahun 2014 (Edisi Revisi) semester 1, yaitu 6.6\% tingkat C2-faktual; $17 \%$ tingkat C2-konseptual; 22\% tingkat $\mathrm{C}_{2}$-prosedural; 3\% tingkat $\mathrm{C}_{3}$-faktual; $6.6 \%$ tingkat $\mathrm{C}_{3}$-konseptual; $28 \%$ tingkat $\mathrm{C}_{3}$-prosedural; $1.8 \%$ tingkat $\mathrm{C}_{4}$-konseptual; $14 \%$ tingkat $\mathrm{C}_{4}$-prosedural; $0.6 \%$ tingkat $\mathrm{C} 6$ konseptual; dan $0 \%$ pertanyaan tingkat yang lainnya. Dan persentase tingkat kognitif soal Uji Kompetensi pada Buku Sekolah Elektronik (BSE) SMP/MTs kelas VII kurikulum 2013 terbitan Kementrian Pendidikan dan Kebudayaan (Kemdikbud) pada tahun 2014 (Edisi Revisi) semester 2, yaitu $0.6 \%$ tingkat $C_{1}$-faktual; 0.6\% tingkat $\mathrm{C}_{1}$-konseptual; $2.9 \%$ tingkat $\mathrm{C}_{2}$ faktual; $15 \%$ tingkat C2-konseptual; $15 \%$ tingkat C2-prosedural; $8.2 \%$ tingkat $\mathrm{C}_{3}$-konseptual; 30\% tingkat $C_{3}$-prosedural; $4.7 \%$ tingkat $\mathrm{C}_{4}$-konseptual; $5.3 \%$ tingkat $\mathrm{C}_{4}$-prosedural; $14 \%$ tingkat $\mathrm{C}_{5}$-konseptual; $4.1 \%$ tingkat $\mathrm{C} 6$ konseptual; dan $0 \%$ tingkat yang lain.

Sedangkan saran yang dapat dikemukakan berdasarkan hasil penelitian ini adalah sebagi berikut: (a) Bagi guru matematika SMP, dalam menggunakan soal uji kompeten- si pada Buku Sekolah Elektronik (BSE) hendaknya terlebih dahulu menyeleksi tingkat kognitif soal tersebut, sehingga soal yang diberikan kepada siswa sesuai dengan tingkat kognitifnya; (b) Bagi penulis dan penerbit Buku Sekolah Elektronik (BSE), hasil akhir dapat dijadikan bahan masukan dalam merevisi buku selanjutnya terutama dalam pembuatan soal sehingga mencakup semua tingkatan Taksonomi Bloom; (c) Bagi peneliti lain, jika ingin melakukan penelitian yang serupa sebaiknya memahami secara utuh tentang masing-masing tingkatan kognitif menurut Revisi Taksonomi Bloom serta ada baiknya jika soal diujikan kepada siswa sehingga hasil penelitian setiap tingkatan kognitif lebih terlihat dari kegiatan siswa dalam mengerjakan soal-soal tersebut.

\section{DAFTAR PUSTAKA}

Arikunto, S. (2002). Metodologi Penelitian Suatu Pendekatan Proposal. Jakarta: PT. Rineka Cipta.

Gunawan, I., \& Palupi, A. R. (2015). Taksonomi Bloomrevisi ranah kognitif: kerangka landasan untuk pembelajaran, pengajaran, dan penilaian. Premiere Educandum, 2(2).

Hudojo, H. (2003). Pengembangan Kurikulum dan Pembelajaran Matematika. Malang: Universitas Negeri Malang.

Kamid. (2013). Metakognisi Siswa Dalam Menyelesaikan Soal Matematika (Studi Kasus pada Siswa SMP Berdasarkan Gender). Edumatica, 3(1): 1-9.

Kemdikbud. 2013. Skor PISA: Posisi Indonesia Nyaris Jadi Juru Kunci. http://www.kopertis12. or.id/2013/12/o5/skor-pisa-posisi-indonesianyaris-jadi-juru-kunci.html. [17 Desember 2014].

Nasrulloh, A.H. (2011). Analisis Tingkat Kognitif Tes Kompetensi Pada Buku Sekolah Elektronik (Bse) Matematika Smp/Mts Kelas Ix Berdasarkan Taksonomi Bloom (Doctoral dissertation). Universitas Negeri Jember

Sugiyono. (2007). Memahami Penelitian Kualitatif. Bandung: Alfabeta.

Tarigan, H.G. \& D. Tarigan. (1990). Telaah Buku Teks Bahasa Indonesia. Bandung: Angkasa.

Widodo, A. (2006). Revisi Taksonomi Bloom dan Pengetahuan Butir Soal. Buletin. Puspendik. 3(2):18-29. 